\title{
MEASUREMENT OF LOSSES IN DIRECT TORQUE CONTROLLED PERMANENT MAGNET SYNCHRONOUS MOTOR BY ANALYSIS AND EXPERIMENTAL SETUP
}

\author{
A N Gokulprakash ${ }^{1}$, A Sivaprakasam ${ }^{2}$, T Manigandan ${ }^{3}$ \\ ${ }^{1}$ P.G Scholar, Department of EEE, Kongu Engineering College, TamilNadu, India \\ ${ }^{2}$ Assistant Professor (Selection Grade), Department of EEE, Kongu Engineering College, TamilNadu, India \\ ${ }^{3}$ Principal, P.A. College of Engineering and Technology, Tamil Nadu, India
}

\begin{abstract}
Direct Torque Control (DTC) appears as an effective and practical control scheme for AC motor drives. The DTC of Permanent Magnet Synchronous Motors (PMSM) Drives attracted great attention, due to many features like high efficiency, quick dynamic performance and provide excellent steady state response. The adjustable speed drives are rapidly introduced in the area of electric vehicle and motion control devices and these devices are often powered by a battery source. Due to the restriction in energy supply, the improvement of motor efficiency is the most important priority, and hence the DTC technique is used to measure the losses in PMSM. In order to measure the losses, the offline and online calculation methods are proposed. In this work, the mechanical losses is depends on rotor speed and friction torque, and it is often uncontrollable but the electrical losses are controllable and hence the electrical losses can be measured certainly. The Offline control method is used for optimizing the steady-state efficiency of PMSM under DTC. In this proposed work, the losses are calculated by offline method for simulation and experimental setup in order to obtain the better steady state efficiency, and also comparatively investigated with analysis and experimental results.
\end{abstract}

Keywords: Permanent Magnet Synchronous Motors, Direct Torque Control and Electrical Losses

\section{INTRODUCTION}

The technology has been developed in many industrial driving systems. The development of the switching speeds of the equipment has enabled the control techniques which have high switching frequency and feasibility of high efficiency driving systems.

However, the induction motor's efficiency changes with slip value from its desire reactive current, and it not able to produce high torque / weight ratio which needed for high performance applications such as robotics. The Switched reluctance motor (SRM) [5], has high reliability due to its simple and robust rotor structure. However, the core loss in the solid rotor is very large at super high-speed. Lamination of the rotor can reduce the core loss in the rotor. However, it is not recommended at super high-speeds since it will reduce critical speeds. Therefore, the different solutions are being studied and dissimilar motor designs have been developed. One of these recently urbanized motors is the permanent magnet synchronous motor. In this, the applications where high concert is demanded, some properties of the permanent magnet synchronous motor such as high power, high torque, high efficiency and low noise have made it more popular compared to other alternating current motors.
Especially, because of the high power density the permanent magnet synchronous motor is related for areas such as automation, robotics, and aeronautics technologies. Since the excitation flux is abounding by the magnets and due to the magnet characteristics and position the permanent magnet synchronous motors have both synchronous machine and a direct current machine characteristics

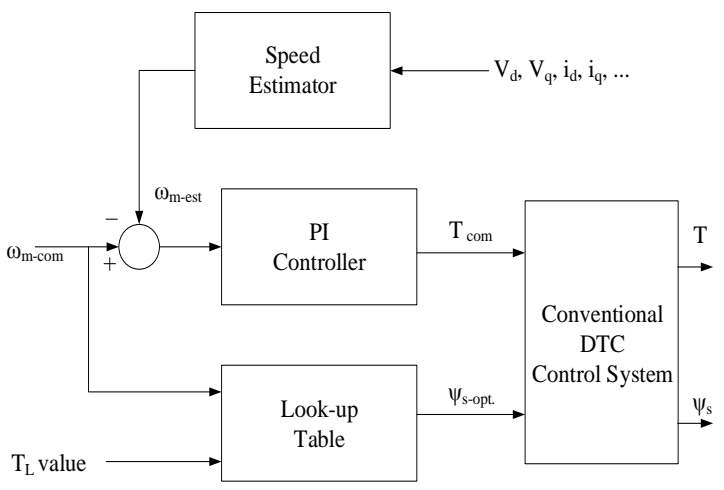

Fig -1: Proposed DTC

The Fig -1 shows the proposed DTC [6] [18] block diagram, for getting the optimized efficiency for a PMS motor drive. The machine terminal voltage and current can be estimated 
from the drive and it given to the input of a speed estimator for estimating the speed of a machine. By comparing, the estimated speed and reference speed which has been given to the controller of PI. The output of PI is given to the DTC block for controlling the drive.

The PMSM offers the advantage of high efficiency compared to other types of motors since there is no excitation power loss in the rotor, and low eddy current loss in the stator and rotor [17]. Therefore, there is an increasing interest to consider PMSM for super high-speed applications. For unloaded conditions, the velocity is directly proportional to voltage and it is inversely proportional to the flux and, for loaded conditions it is proportional to the flux and current. The Synchronous motors have three phase windings in their stators, just like the induction motors [3]. Though, the rotor structure is different.

The permanent magnet synchronous motor (PMSM) [14], becoming more and more attractive due to its high efficiency and high torque to current ratio For a PMSM drive system mechanical sensors are often required for correct commutation of the inverters [2]. The use of mechanical sensors however reduces the reliability and increases the cost of the system. To overcome this disadvantage sensor less control scheme is much desirable. Recently the Direct Torque Control (DTC) [9] [10], scheme is increasingly used in PMSM drive systems because of its fast torque response and possibility of eliminating the mechanical sensors if the initial rotor position is known.

\section{MACHINE MODEL}

The minimization of electrical loss [5] [7], in PMS motor drive necessitates consideration of copper and iron losses in the machine model. An equivalent circuit model of a PMS machine in synchronously rotating reference frame is used through following equations. The $\mathrm{d}$ - and the $\mathrm{q}$-axis stator flux linkage components are:

$$
\begin{aligned}
& \psi_{\mathrm{q}}=\mathrm{L}_{\mathrm{q}} \mathrm{i}_{\mathrm{oq}} \\
& \psi_{\mathrm{d}}=\psi_{\mathrm{m}}+\mathrm{L}_{\mathrm{d}} \mathrm{i}_{\mathrm{od}}
\end{aligned}
$$

The electro-magnetic torque in terms of the torque producing currents, $i_{\text {od }}$ and $i_{\text {oq }}$ is given as:

$$
\mathrm{T}_{\mathrm{e}}=\mathrm{Pi}_{\mathrm{oq}}\left[\psi_{\mathrm{m}}+\left(\mathrm{L}_{\mathrm{d}}-\mathrm{L}_{\mathrm{q}}\right) \mathrm{i}_{\mathrm{od}}\right]
$$

The motor drive system dynamics is also signified by:

$$
\mathrm{T}_{\mathrm{e}}=\mathrm{T}_{\mathrm{L}}+\mathrm{B}\left(\omega_{\mathrm{m}}\right)+\mathrm{J} \frac{\mathrm{d} \omega_{\mathrm{m}}}{\mathrm{dt}}
$$

In the steady state we have,

$$
\begin{gathered}
\omega_{\mathrm{m}}=\left(\omega_{\mathrm{m}}\right) \text { com. } \\
\mathrm{T}_{\mathrm{e}}=\mathrm{T}_{\mathrm{ss}}=\mathrm{T}_{\mathrm{L}}+\mathrm{B}\left(\omega_{\mathrm{m}}\right) \text { com. }
\end{gathered}
$$

Mechanical loss depends on rotor speed and friction torque and often is un-controllable,

$$
\mathrm{W}_{\mathrm{M}}=\mathrm{T}_{\mathrm{mech}}{ }^{\omega_{\mathrm{m}}}
$$

Electrical loss consists of iron loss and copper loss, therefore, the following equations are,

$$
\begin{gathered}
\mathrm{W}_{\mathrm{E}}=\mathrm{W}_{\mathrm{cu}}+\mathrm{W}_{\mathrm{fe}} \\
\mathrm{W}_{\mathrm{E}}=\mathrm{R}_{\mathrm{S}}\left(\mathrm{i}_{\mathrm{d}}^{2}+\mathrm{i}_{\mathrm{d}}^{2}\right)+\mathrm{R}_{\mathrm{c}}\left(\mathrm{i}_{\mathrm{cd}}^{2}+\mathrm{i}_{\mathrm{cd}}^{2}\right) \\
\mathrm{W}_{\text {LOSS }}=\mathrm{W}_{\mathrm{M}}+\mathrm{W}_{\mathrm{E}}
\end{gathered}
$$

The machine efficiency is a function of output power and loss terms, as:

$$
\eta=\frac{\mathrm{p}_{\text {out }}}{\mathrm{p}_{\text {out }}+\mathrm{w}_{\text {LOSS }}}
$$

\section{PROBLEM FORMULATION}

The electrical loss relation has been simplified and appropriate formulation of the loss minimization problem, has been introduced. Fig -2 shows the equivalent circuit for PMSM, we have

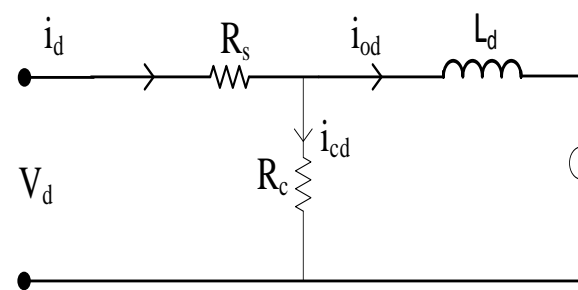

$\omega e \mathrm{~L}_{q} \mathrm{i}_{\mathrm{q}}$

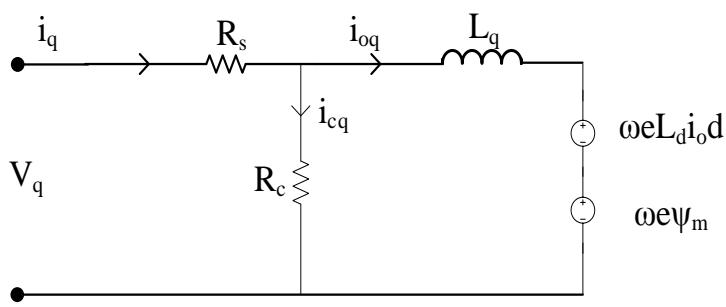

Fig -2: Equivalent circuit for PMSM 


$$
\begin{gathered}
\mathrm{i}_{\mathrm{cd}}=\frac{\mathrm{V}_{\mathrm{d}}-\mathrm{R}_{\mathrm{s}} \mathrm{i}_{\text {od }}}{\mathrm{R}_{\mathrm{s}}+\mathrm{R}_{\mathrm{c}}} \text { and } \mathrm{i}_{\mathrm{d}}=\frac{\mathrm{V}_{\mathrm{d}}+\mathrm{R}_{\mathrm{c}} \mathrm{i}_{\text {od }}}{\mathrm{R}_{\mathrm{s}}+\mathrm{R}_{\mathrm{c}}} \\
\mathrm{i}_{\mathrm{cq}}=\frac{\mathrm{V}_{\mathrm{q}}-\mathrm{R}_{\mathrm{s}} \mathrm{i}_{\mathrm{oq}}}{\mathrm{R}_{\mathrm{s}}+\mathrm{R}_{\mathrm{c}}} \text { and } \mathrm{i}_{\mathrm{q}}=\frac{\mathrm{V}_{\mathrm{q}}+\mathrm{R}_{\mathrm{s}} \mathrm{i}_{\text {oq }}}{\mathrm{R}_{\mathrm{s}}+\mathrm{R}_{\mathrm{c}}} \\
\mathrm{W}_{\mathrm{E}}=\frac{\mathrm{V}_{\mathrm{S}}^{2}}{\mathrm{R}_{\mathrm{S}}+\mathrm{R}_{\mathrm{c}}}+\frac{\mathrm{R}_{\mathrm{s}} \mathrm{R}_{\mathrm{c}}}{\mathrm{R}_{\mathrm{s}}+\mathrm{R}_{\mathrm{c}}}\left[\mathrm{i}_{\text {od }}^{2}+\mathrm{i}_{\mathrm{oq}}^{2}\right] \\
\mathrm{i}_{\text {oq }}=\frac{\psi_{\mathrm{q}}}{\mathrm{L}_{\mathrm{q}}} \quad \mathrm{i}_{\text {od }}=\frac{\psi_{\mathrm{q}}-\psi_{\mathrm{m}}}{\mathrm{L}_{\mathrm{d}}}
\end{gathered}
$$

Substituting the $i_{\text {oq }}$ and $i_{\text {od }}$ into equation,

$$
\mathrm{W}_{\mathrm{E}}=\frac{\mathrm{V}_{\mathrm{S}}^{2}}{\mathrm{R}_{\mathrm{S}}+\mathrm{R}_{\mathrm{c}}}+\frac{\mathrm{R}_{\mathrm{s}} \mathrm{R}_{\mathrm{c}}}{\mathrm{R}_{\mathrm{S}}+\mathrm{R}_{\mathrm{c}}}\left[\left[\frac{\psi_{\mathrm{d}}-\psi_{\mathrm{m}}}{\mathrm{L}_{\mathrm{d}}}\right]^{2}+\left[\frac{\psi_{\mathrm{q}}}{\mathrm{L}_{\mathrm{q}}}\right]^{2}\right]
$$

Where,

$$
\mathrm{v}_{\mathrm{s}}^{2}=\mathrm{v}_{\mathrm{d}}^{2}+\mathrm{v}_{\mathrm{q}}^{2}
$$

$\mathrm{V}_{\mathrm{s},}$ is the magnitude of the stator voltage. In DTC method the magnitude of the stator voltage is always constant. The first term in the above equation is always constant. This term represents the "unavoidable electrical loss in direct torque control of PMSM". Therefore, second term is decreased. The variable part as "Performance Index" has been considered.

Therefore, the optimization problem becomes Minimize

$$
J=\left[\left[\frac{\psi_{d}-\psi_{m}}{L_{d}}\right]^{2}+\left[\frac{\psi_{q}}{L_{q}}\right]^{2}\right]
$$

This optimization problem is subject to steady state torque generation constraint.

$$
\mathrm{T}_{\mathrm{Ss}}=\frac{3}{2} \mathrm{p} \psi_{\mathrm{q}}\left[\left[\frac{1}{\mathrm{~L}_{\mathrm{d}}}\right] \psi_{\mathrm{m}}+\left[\frac{1}{\mathrm{~L}_{\mathrm{q}}}-\frac{1}{\mathrm{~L}_{\mathrm{d}}}\right] \psi_{\mathrm{d}}\right]
$$

For different values of $\mathrm{T}_{\mathrm{ss}}$ obtained from (6), this equation characterizes different hyperbolic trajectories in $\left(\psi_{\mathrm{d}}, \psi_{\mathrm{q}}\right)$ plane.

$$
\begin{aligned}
& \frac{2 \mathrm{~T}_{\mathrm{ss}}}{3 \mathrm{p} \psi_{\mathrm{q}}}=\left[\frac{1}{\mathrm{~L}_{\mathrm{d}}}\right] \psi_{\mathrm{m}}+\left[\frac{1}{\mathrm{~L}_{\mathrm{q}}}-\frac{1}{\mathrm{~L}_{\mathrm{d}}}\right] \psi_{\mathrm{d}} \\
& \psi_{\mathrm{q}}=\frac{2 \mathrm{~T}_{\mathrm{ss}}}{3 \mathrm{p}\left[\frac{1}{\mathrm{~L}_{\mathrm{d}}}\right] \psi_{\mathrm{m}}+\left[\frac{1}{\mathrm{~L}_{\mathrm{q}}}-\frac{1}{\mathrm{~L}_{\mathrm{d}}}\right] \psi_{\mathrm{d}}}
\end{aligned}
$$

Substitute the $\psi_{\mathrm{q}}$ into equation number (18)

$$
\begin{gathered}
\left.J=\left[\frac{\psi_{d}-\psi_{m}}{L_{d}^{2}}\right]^{2}+\left[\frac{3 p\left[\frac{1}{L_{d}}\right] \psi_{m}+\left[\frac{1}{L_{q}}-\frac{1}{L_{d}}\right] \psi_{d}}{L_{q}}\right]^{2}\right] \\
\frac{\partial J}{\partial \psi_{d}}=2\left[\frac{\psi_{d}-\psi_{m}}{L_{d}^{2}}\right]-2 \frac{4 T_{S s}^{2}}{9 p^{2} L_{q}^{2}}\left[\left[\frac{1}{L_{d}}\right] \psi_{m}+\left[\frac{1}{L_{q}}-\frac{1}{L_{d}}\right] \psi_{d}\right]^{-3}\left[\left[\frac{1}{L_{q}}-\frac{1}{L_{d}}\right]\right]
\end{gathered}
$$

\section{OPTIMUM STATOR FLUX LINKAGE DETERMINATION}

Obtaining the $\psi_{\mathrm{q}}$ component from (19) and substitution in (18), yields the performance index as a function $\psi_{\mathrm{d}}$ of only. Now, it is possible to differentiate $\mathrm{J}$ with respect to $\psi_{\mathrm{d}}$ to find the optimum $\psi_{\mathrm{d}}$

$$
\begin{gathered}
\frac{\partial J}{\partial \psi_{d}}=0 \\
\left.\left[\frac{\psi_{\mathrm{d}}-\psi_{\mathrm{m}}}{\mathrm{L}_{\mathrm{d}}^{2}}\right]=\frac{4 \mathrm{~T}_{\mathrm{SS}}^{2}}{9 \mathrm{p}^{2} \mathrm{~L}_{\mathrm{q}}^{2}}\left[\left[\frac{1}{\mathrm{~L}_{\mathrm{d}}}\right] \psi_{\mathrm{m}}+\left[\frac{1}{\mathrm{~L}_{\mathrm{q}}}-\frac{1}{\mathrm{~L}_{\mathrm{d}}}\right] \psi_{\mathrm{d}}\right]\left[\frac{1}{\mathrm{~L}_{\mathrm{q}}}-\frac{1}{\mathrm{~L}_{\mathrm{d}}}\right]\right] \\
\left.\left[\frac{\psi_{\mathrm{d}}-\psi_{\mathrm{m}}}{\mathrm{L}_{\mathrm{d}}^{2}}\right]=\left[\frac{4 \mathrm{~T}_{\mathrm{SS}}^{2}}{9 \mathrm{p}^{2} \mathrm{~L}_{\mathrm{q}}^{2}}\right] * \frac{1}{\left[\frac{1}{\mathrm{~L}_{\mathrm{q}}}-\frac{1}{\mathrm{~L}_{\mathrm{d}}}\right]}\left[\frac{1}{\mathrm{~L}_{\mathrm{d}}}\right] \psi_{\mathrm{m}}+\left[\frac{1}{\mathrm{~L}_{\mathrm{q}}}-\frac{1}{\mathrm{~L}_{\mathrm{d}}}\right] \psi_{\mathrm{d}}\right]^{3}
\end{gathered}
$$


The following equation is obtaining, for the optimum $\psi_{\mathrm{d}}$

$$
\mathrm{a} \psi_{\mathrm{d}}^{4}+\mathrm{b} \psi_{\mathrm{d}}^{3}+\mathrm{c} \psi_{\mathrm{d}}^{2}+\mathrm{d} \psi_{\mathrm{d}}+\mathrm{e}=0
$$

$$
\begin{aligned}
& \text { Where } \\
& \begin{aligned}
\mathrm{a}= & \left(\mathrm{L}_{\mathrm{d}}-\mathrm{L}_{\mathrm{q}}\right)^{3} \\
\mathrm{~b} & =\psi_{\mathrm{m}}\left(4 \mathrm{~L}_{\mathrm{q}}^{3}-\mathrm{L}_{\mathrm{d}}^{3}-9 \mathrm{~L}_{\mathrm{d}} \mathrm{L}_{\mathrm{q}}^{2}+6 \mathrm{~L}_{\mathrm{d}}^{2} \mathrm{~L}_{\mathrm{q}}\right) \\
\mathrm{c} & =\psi_{\mathrm{m}}^{2}\left(9 \mathrm{~L}_{\mathrm{d}} \mathrm{L}_{\mathrm{q}}^{2}-6 \mathrm{~L}_{\mathrm{q}}^{3}-3 \mathrm{~L}_{\mathrm{d}}^{2} \mathrm{~L}_{\mathrm{q}}\right) \\
\mathrm{d} & =\psi_{\mathrm{m}}^{3}\left(4 \mathrm{~L}_{\mathrm{q}}^{3}-3 \mathrm{~L}_{\mathrm{d}} \mathrm{L}_{\mathrm{q}}^{2}\right) \\
\mathrm{e} & =\frac{4 \mathrm{~T}_{\mathrm{ss}}^{2} \mathrm{~L}_{\mathrm{d}}^{4}}{9 \mathrm{P}^{2}}\left(\mathrm{~L}_{\mathrm{d}}-\mathrm{L}_{\mathrm{q}}\right) \psi_{\mathrm{m}}^{4} \mathrm{~L}_{\mathrm{q}}^{3}
\end{aligned}
\end{aligned}
$$

It is possible to derive the closed-form solution of (27) for salient-pole PMS machine where $\mathrm{L}_{\mathrm{d}}=\mathrm{L}_{\mathrm{q}}$. In this case, the solution is as follows:

Steady state torque

$$
\left(\psi_{\mathrm{q}}\right)_{\mathrm{opt} .}=\frac{2 \mathrm{~T}_{\mathrm{ss}} \mathrm{L}_{\mathrm{d}}}{3 \mathrm{P} \psi_{\mathrm{m}}}
$$

From this, optimum stator flux linkage can be calculated, for the optimized efficiency;

$$
\left(\psi_{\mathrm{s}}\right)_{\text {opt. }}=\sqrt{\left(\psi_{\mathrm{d}}\right)_{\text {opt. }}^{2}+\left(\psi_{\mathrm{q}}\right)_{\text {opt. }}^{2}},\left(\psi_{\mathrm{d}}\right)_{\text {opt. }}=\psi_{\mathrm{m}}
$$

\section{ONLINE CALCULATION}

In this online calculation, to find the optimum stator flux linkage for obtaining the better efficiency. An important point in DTC is that the magnitude of the stator flux linkage is controlled and there is no control on the components of the stator current or stator flux in $\mathrm{d}$ or $\mathrm{q}$ axis [18]. That the optimization problem can be solved more easily in terms of $\psi_{\mathrm{d}}$ and $\psi_{\mathrm{q}}$ rather than $\psi_{\mathrm{s}}$ and $\delta$ (angle of flux vector in the $\psi_{\mathrm{d}}-\psi_{\mathrm{q}}$ plane). Loss minimization of PMS machines has been dealt with in the vector control framework. As shown before, some parts of electrical loss of DTC strategy are unavoidable and loss minimization procedure deals with another part. Therefore, the optimization here is substantially different from that performed in vector control.

The reference speed and the load torque can be given to the input to the lookup table for calculating the optimized stator flux linkage. The obtained stator flux linkage and output of PI controller can be given to the conventional DTC control system. Normally, for obtaining the optimized solution, they handle the many algorithms for getting the better efficiency. In this proposed scheme, the conventional DTC has been used to the control system for efficiency optimization of PMS machine. For desired set point and existing load torque, find an optimum stator flux linkage from look-up table. Use the optimized stator flux linkage as an optimal stator flux command in DTC procedure. In this online calculation, the desired efficiency has been obtained from the offline calculation. From, the offline calculation the optimized stator flux linkage had obtained from the PMS machine model.

\section{SIMULATION RESULTS}

The Simulation Results for $\psi_{\mathrm{d}}$ and $\psi_{\mathrm{q}}$ is shown in Fig -3 and Fig -4 .

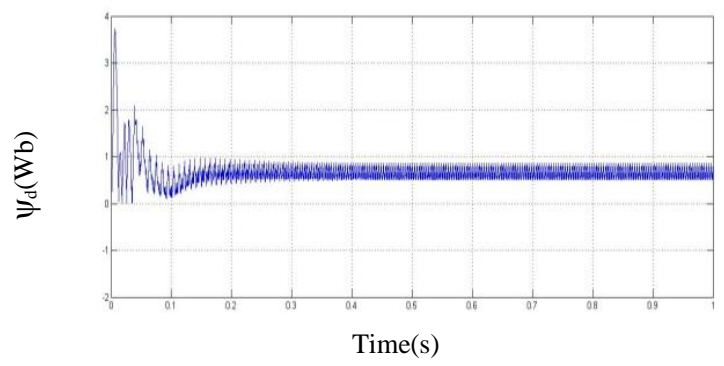

Fig -3: D-Axis Stator Flux Linkage Component

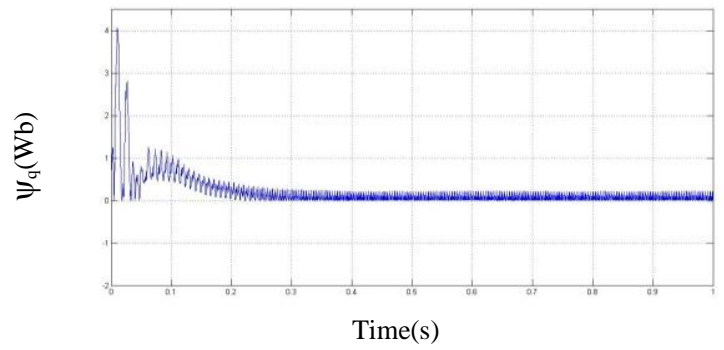

Fig -4: Q-Axis Stator Flux Linkage Component

The stator flux components and electrical losses are depicted in Fig -3 through Fig -4 in addition, flux components and electrical loss are depicted for a typical non optimum $\psi_{\mathrm{s}}$ value $\left(\psi_{\mathrm{s}}=1.25 \mathrm{~Wb}\right)$. Note that although the flux control system only controls the magnitude of stator flux, the $\psi_{\mathrm{d}}$ and $\psi_{\mathrm{q}}$ converges to their optimal values. $\psi_{\mathrm{d}}$ values settles at $1.25 \mathrm{~Wb}$ from peak value of $2.75 \mathrm{~Wb}$ and $\psi_{\mathrm{q}}$ values settles at $1.25 \mathrm{~Wb}$ from $3.25 \mathrm{~Wb}$ by online control method.

Fig -5 shows the simulation results for the electrical losses, a desirable torque response shows that the proposed efficiency optimization system does not deteriorate the effectiveness of torque control. The stator flux components and electrical loss are depicted in Fig -10 . The electrical loss value is 147.51 (W). 


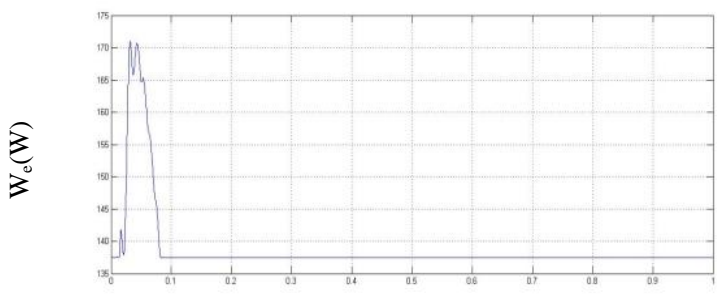

Time(s)

Fig -5: Electrical Loss

The simulation results for PMSM efficiency is shown in the Fig -6. Desirable torque response shows that the proposed efficiency optimization system does not deteriorate the effectiveness of torque control. In addition, flux components and electrical loss are depicted for a typical non-optimum value.

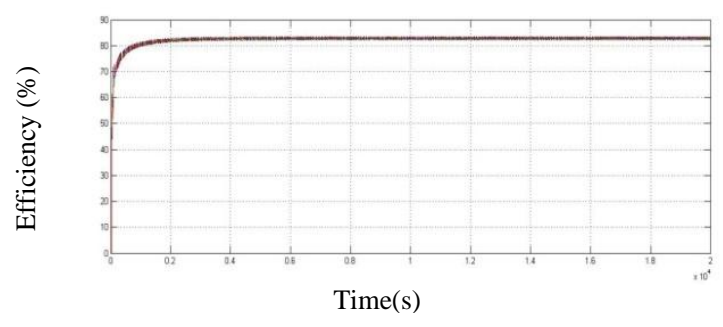

Fig -6: PMSM Efficiency

The efficiency value is $80(\%)$. The load torque is equal to the rated torque of the PMS machine i.e. 3.0 Nm. The desired speed is as before. With these values $\mathrm{T}_{\mathrm{ss}}=3.0$ (N.m.) and optimization procedure results $\left(\psi_{\mathrm{d}}\right)_{\mathrm{opt}}=1.25(\mathrm{~Wb})$ and $\left(\psi_{\mathrm{q}}\right)$ opt. $=1.25(\mathrm{~Wb})$ and consequently. In addition, to verify the robustness of closed loop system to load disturbances, the load torque increased to $3 \mathrm{Nm}$ in $0.1 \mathrm{sec}$ at $1 \mathrm{sec}$ period.

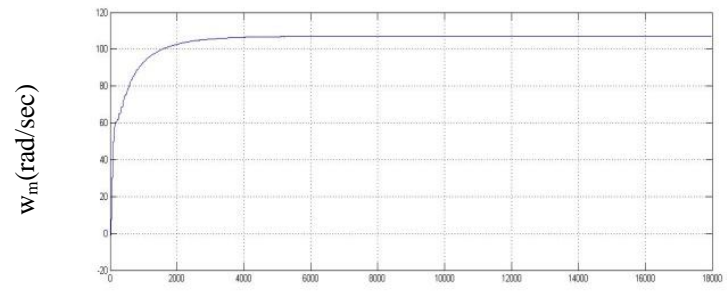

Time(s)

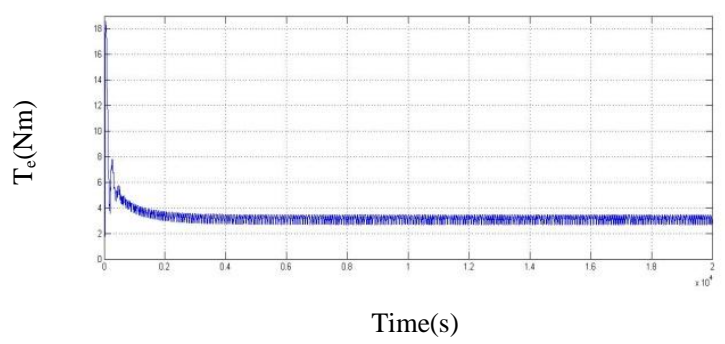

Fig -7: Electro-Magnetic Torque and Hysteresis Bands, Actual Motor Speed
Fig -8 shows Simulation Result for Electro-Magnetic Torque, Hysteresis Bands and Actual Speed. The motor speed control can perform disturbance compensation task and desired speed is obtained after a short transient time. The electro-magnetic torque value is $3(\mathrm{Nm})$ and Actual motor speed value is 107 $(\mathrm{rad} / \mathrm{sec})$.

In this loss measurement of DTC PMSM used offline control method and online control method to enhance the efficiency of traditional control of the motor. The offline values can be calculated from the machine model. By using the values of offline, for simulate the online control method values of using optimized stator flux linkage $\psi_{\mathrm{s}}$. This can be achieved from daxis stator flux linkage $\psi_{\mathrm{d}}$ and $\mathrm{q}$ axis stator flux linkage $\psi_{\mathrm{q}}$.

Table -1: Quantitative comparative study for optimized efficiency

\begin{tabular}{|l|c|c|}
\hline Proposed PMSM & $\begin{array}{c}\text { Electrical } \\
\text { Losses(W) }\end{array}$ & Efficiency (\%) \\
\hline $\begin{array}{l}\text { Speed }=1000 \mathrm{rpm} \\
\text { Torque }=\text { No load }\end{array}$ & 120.53 & 89.30 \\
\hline $\begin{array}{l}\text { Speed }=1000 \mathrm{rpm} \\
\text { Torque }=1 \mathrm{Nm}\end{array}$ & 127.31 & 87.35 \\
\hline $\begin{array}{l}\text { Speed }=1000 \mathrm{rpm} \\
\text { Torque }=1.5 \mathrm{Nm}\end{array}$ & 131.52 & 86.40 \\
\hline $\begin{array}{l}\text { Speed }=1000 \mathrm{rpm} \\
\text { Torque }=2 \mathrm{Nm}\end{array}$ & 136.29 & 85.40 \\
\hline $\begin{array}{l}\text { Speed }=1000 \mathrm{rpm} \\
\text { Torque }=2.5 \mathrm{Nm}\end{array}$ & 141.72 & 84.27 \\
\hline $\begin{array}{l}\text { Speed }=1000 \mathrm{rpm} \\
\text { Torque }=3 \mathrm{Nm}\end{array}$ & 147.51 & 83.00 \\
\hline
\end{tabular}

Although the flux control system only controls the magnitude of stator flux, the $\psi_{\mathrm{d}}$ and $\psi_{\mathrm{q}}$ converges to their optimal value found due to torque generation constraints. The electrical loss can be depicted through the optimized stator flux $\psi_{\mathrm{s} \text {. The }}$ electrical loss can be simulated using the optimized stator flux linkage $\psi_{\mathrm{s}}$. The flux components and electrical losses can be inferred from the non optimal values. The resulted PMSM efficiency graph shows the motor speed control can perform the disturbance compensation task and desired speed is obtained after a short time. The efficiency denotes the motor speed and motor torque. By varying the load from 0 to $4 \mathrm{Nm}$ at a constant speed of 1000rpm has achieved a optimized efficiency. At a speed of 1000rpm and a motor torque of $1 \mathrm{Nm}$ has $87.35 \%$ of electrical loss is 127.31 watts and no load of $89.30 \%$ of electrical loss is 120.53 watts achieved a better efficiency.

\section{EXPERIMENTAL RESULTS}

Energy efficient pulse width modulation inverters are widely used to control electrical machine accurately for process needs. The pulse width modulation has adverse effect and produce additional losses in the motor. These losses increases 
the motor temperature and degrading of the machine power in converter use. For the performance prediction of the variable speed drives a reliable and reasonably accurate loss model of a PMSM drive system is important. Measurement were taken under no load and load condition for PWM supplies.

\subsection{No Load Condition}

The motor has been tested under the no load condition as per the motor nameplate data, together with parameter derived from the test are presented in Table -2 .

Table -2: No load condition operating at a speed of $50 \mathrm{~Hz}$

\begin{tabular}{|c|c|}
\hline Operating condition & Without usage of DTC \\
\hline Voltage(V) & 154 \\
\hline Current(A) & 0.3 \\
\hline Input power(W) & 79.22 \\
\hline Synchronous speed(RPM) & 1500 \\
\hline Speed (RPM) & 1498 \\
\hline Output power(W) & 80 \\
\hline
\end{tabular}

\subsection{Load Condition}

The motor was tested under the range of load condition, for PWM supply conditions and also the various losses was calculated for rated speed as well as the better efficiency has been achieved for PWM inverter. Table -3 indicates the losses are calculated at $50 \mathrm{~Hz}$ operating point.

Table -3: Indicates the load condition operating at a frequency of $50 \mathrm{~Hz}$

\begin{tabular}{|c|c|}
\hline Operating condition & Without usage of DTC \\
\hline Voltage (V) & 151 \\
\hline Current (A) & 1.25 \\
\hline Input power (W) & 199.42 \\
\hline $\begin{array}{c}\text { Synchronous speed } \\
(\text { RPM) }\end{array}$ & 1500 \\
\hline Speed (RPM) & 1380 \\
\hline Output power (W) & 148.85 \\
\hline Efficiency (\%) & 75 \\
\hline Copper loss (W) & 36.57 \\
\hline Iron loss (W) & 162.85 \\
\hline $\begin{array}{c}\text { Friction and windage } \\
\text { loss (W) }\end{array}$ & 2.7 \\
\hline Core loss (W) & 17 \\
\hline Total loss & 50.57 \\
\hline
\end{tabular}

\subsection{Comparative Analysis of Various Losses with}

\section{Efficiency}

Comparative analysis of various losses like(copper loss, iron or core loss called electrical loss and friction and windage loss also called as mechanical loss) with efficiency operating at a frequency of $50 \mathrm{~Hz}$.

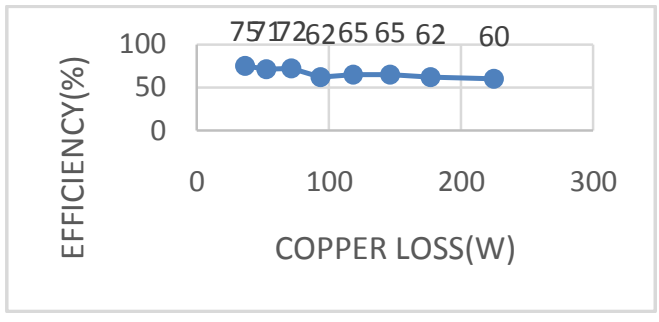

Fig -9: Efficiency Vs Copper Loss

Fig -9 shows that the, Copper losses increase as the value of electrical current passing through the conductors increases. An rise in the temperature of the wire or conductor causes the resistance of the wire to increase causing the copper losses to also increase. Copper losses result from Joule heating stating that the energy lost increases as the square of the current through the wire and is in proportion of the electrical resistance of the conductors.

Copper Loss $=\mathrm{I}^{2} \mathrm{R}$

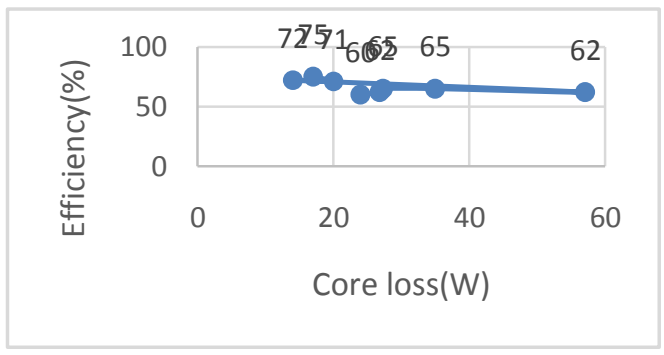

Fig -10: Efficiency Vs Core Loss

Fig -10 shows that the lamination of core area increases the resistance value has to be decreases at a time the iron loss to be more. Since the decreases of core area the efficiency is achieved high.

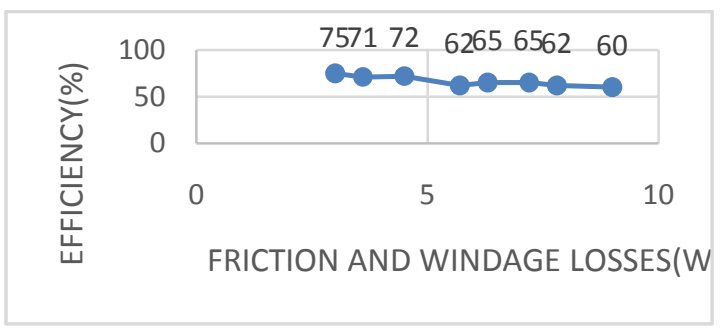

Fig -11: Efficiency Vs Friction and windage Loss 
Fig -11 shows that the mechanical losses occur at the bearing and brush friction loss occurs in wound rotor induction motor. These losses happens with the variation in speed. The speed usually remains constant at three phase induction motor. Hence these losses nearly remains constant.

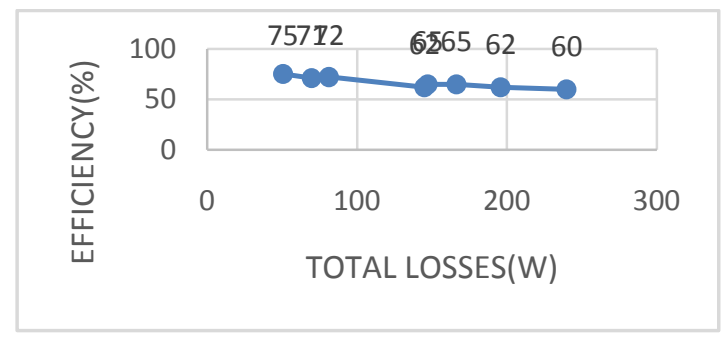

Fig -12: Efficiency Vs Total Loss

Fig -12 shows that the total loss can be calculated by the summation of all above losses.

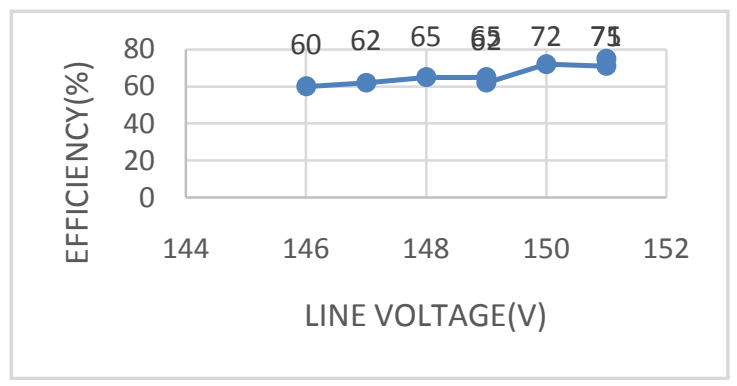

Fig -13: Efficiency Vs Line voltage

In line voltage increases at that time the efficiency gets increased because the efficiency and voltage are directly proportional to each other.

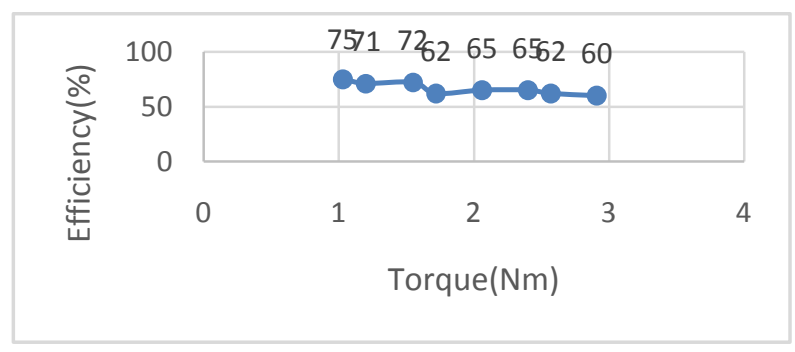

Fig -14: Efficiency Vs Torque

In this fig -14 the torque increases at that time efficiency gets decreased because the torque and efficiency is inversely proportional to each other.

\section{COMPARATIVE STUDY}

The quantitative comparative study for optimized efficiency of PMSM for both simulation and measured result was compared in Table -4 .
Table -4: Shows the comparison of efficiency for Simulation and Experimental setup

\begin{tabular}{|c|c|c|}
\hline $\begin{array}{c}\text { Torque } \\
(\mathrm{Nm})\end{array}$ & $\begin{array}{l}\text { Efficiency of } \\
\text { measured result }(\%)\end{array}$ & $\begin{array}{l}\text { Efficiency of } \\
\text { simulation result }(\%)\end{array}$ \\
\hline 2.9 & 60 & 83 \\
\hline 2 & 65 & 85.40 \\
\hline 1 & 75 & 87.35 \\
\hline
\end{tabular}

\section{CONCLUSIONS}

In this method the optimization of steady state efficiency in direct torque control of permanent magnet synchronous machines is proposed. The optimum stator flux command is found out at any operating point by an off-line procedure such that the minimum electrical loss is obtained. The On-line computations are limited to find the optimum stator flux linkage command from a calculated offline control method. For PMSM machine, the closed form solution of optimum stator flux has been derived. Although, the flux control system only controls the magnitude of stator flux converge to their optimal values due to torque generation constraint. Lower steady state electrical losses are obtained by efficiency optimization approach. In the outcome, the effectiveness of the optimal flux determination procedure has been verified, and the resulted motor speed, the motor torque and efficiency are depicted and motor speed control can perform disturbance compensation task and desired speed is obtained after a short transient time.

The result which has been obtained from the online calculation was done by MATLAB environment and experimentally. The Simulation results also confirm the machine efficiency over a load changes at constant speed. In the measured value of electrical losses the optimized efficiency has been achieved at a load torque of $1 \mathrm{Nm}$ has $87.35 \%$ and no-load of $89.30 \%$ and as compared to simulation the experimental result efficiency has been decreased by $23 \%$ at rated torque.

\section{REFERENCES}

[1] B. Asghari, V. Dinavahi, M. Rioual, J. A. Martinez, and R. Iravani(2009), "Interfacing techniques for electromagnetic field and circuit simulation programs IEEE Task Force on Interfacing Techniques for Simulation Tools," IEEE Trans. Power Del., vol. 24, no. 2, pp. 939-950.

[2] A. Boglietti, A. Cavagnino, and M. Lazzari(2010), "Fast method for the iron loss prediction in inverter-fed induction motors," IEEE Trans. Ind. Appl., vol. 46, no. 2, pp. 806-811.

[3] A. Boglietti, A. Cavagnino, D. M. Ionel, M. Popescu, D. A. Staton, and S. Vaschetto(2010), "A general model to predict the iron losses in PWM inverter-fed 
induction motors," IEEE Trans. Ind. Appl., vol. 46, no. 5, pp. 1882-1890.

[4] A. Boglietti, A. Cavagnino, and A. M. Knight (2008), "Isolating the impact of PWM modulation on motor iron loss," in Conf. Rec. IEEE IAS Annu. Meeting, Edmonton, Canada, pp. 1-7.R. Nicole, "Title of paper with only first word capitalized," J. Name Stand. Abbr ev., in press.

[5] Z. Gmyrek, A. Boglietti, and A. Cavagnino (2010), "Estimation of iron losses in induction motors: Calculation method, results, and analysis," IEEE Trans. Ind. Electron., vol. 57, no. 1, pp. 161-171.

[6] H. Ghassemi and S. Vaez-Zadeh(2005), "A very fast direct torque control for interior permanent magnet synchronous motors start up," Energy Conversion and Management, Vol. 46, No. 5, pp. 715-726.

[7] E. N. Hidebrand and H. Roehrdanz (2001), "Losses in three-phase induction machines fed by PWM converter," IEEE Trans. Energy Convers., vol. 16, no. 3, pp. 228-233.

[8] T. Haring, "Design of motors for inverter operation(2000)," in Energy Efficiency Improvements in Electronic Motors and Drives, P. Bertoldi, A. T. de Almeida, and H. Falkner, Eds. Berlin, Germany: Springer- Verlag.

[9] N. R. N. Idris, C. L. Toh, and M. E. Elbuluk (2006), “A new torque and flux controller for direct torque control of induction machines," IEEE Trans. Ind. Appl., vol. 42 , no. 6 , pp. $1358-1366$.

[10] N. R. N. Idris and A. H. M. Yatim (2004), "Direct torque control of induction machines with constant switching frequency and reduced torque ripple," IEEE Trans. Ind. Electron., vol. 51, no. 4, pp. 758-767.

[11] J.-J. Lee, Y.-K. Kim, H. Nam, K.-H. Ha, J.-P. Hong, and D.-H. Hwang (2004), "Loss distribution of threephase induction machines fed by pulse width modulated inverter," IEEE Trans. Magn., vol. 40, no. 2, pp. $762-765$.

[12] C. Lascu, I. Boldea, and F. Blaabjerg(2004), "Direct torque control of sensorless induction motor drives: A sliding-mode approach," IEEE Trans. Ind. Appl., vol. 40 , no. 2 , pp. 582-590.

[13] A. Ruderman, "Electrical machine PWM loss evaluation basics (2005)," in Proc. Energy Efficiency Motor Driven Syst., Heidelberg, Germany, pp. 58-68.

[14] M. F. Rahman, M. E. Haque, L. Tang and L. Zhong(2004), "Problems associated with the direct torque control of an interior permanent magnet synchronous motor drive and their remedies, "IEEE Trans. Industrial Electronics, Vol. 51, No. 4, pp. 799809.

[15] L. Ruifang, C. C. Mi, and D.W. Gao (2008), "Modelling of iron losses of electrical machines and transformers fed by PWM inverters," IEEE Trans. Magn., vol. 44, no. 8, pp. 2021-2028.
[16] K.-K. Shyu, J. K. Lin, V.-T. Pham, M.-J. Yang, and T.W. Wang(2010), "Global minimum torque ripple design for direct torque control of induction motor drives," IEEE Trans. Ind. Electron., vol. 57, no. 9, pp. 3148-3156.

[17] S. Vaez-Zadeh and F. Hendi (2005), "A continuous efficiency optimization controller for induction motor drives," Energy Conversion and Management, Vol. 46, No. 5, pp. 701-713.

[18] S. Vaez-Zadeh and G. H. Mazarei (2000), "Open loop control of hysteresis band amplitudes in direct torque control of induction machines," in Conf. Rec. 2000 IEEE Industry Application Conf., 8-12, pp. 1519 1524, vol.3.

[19] S. Vaez-Zadeh, V. I. John and M. A. Rahman (1999), "An on-line loss minimization controller for interior permanent magnet motor drives," IEEE Trans. Energy Conversion, vol. 14, pp. 1435-40.

[20] S. Vaez-Zadeh(2001), "Variable flux control of permanent magnet synchronous motor drives for constant torque operation," IEEE Trans. Power Electronics, vol. 16, no. 4, pp. 527-534.

[21] Y. Wu, R. A. McMahon, Y. Zhan, and A. M. Knight (2006), "Impact of PWM schemes on induction motor losses," in Conf. Rec IEEE 41st Ind. Appl. Conf., vol. 2, pp. 813-818.

[22] Y. Wu, S. Shao, and R. A. McMahon(2008), "Power loss study of inverter-fed machine drives using discontinuous pulse width modulation," in Proc. IEEE Ind. Conf Sustainable Energy Technol., pp. 1172-1177.

[23] Y. Wu, M. A. Shafi, A. M. Knight, and R. A. McMahon(2011), "Comparison of the effects of continuous and discontinuous PWM schemes on power losses of voltage-sourced inverters for induction motor drives," IEEE 7Trans. Power Electron., vol. 26, no. 1, pp. 182-191.

[24] K. Yamazaki and N. Fukushima(2010), "Iron loss model for rotating machines using direct eddy current analysis in electrical steel sheets," IEEE Trans. Energy Convers., vol. 25, no. 3, pp. 633-641.

[25] Y. Zhan, A. M. Knight, Y. Wu, and R. A. McMahon (2008), "Investigation and comparison of inverter-fed induction machine loss," in Proc. IEEE Ind. Appl. Soc. Annu. Meeting, pp. 1-6.

\section{BIOGRAPHIE}

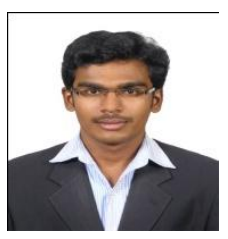

A.N.Gokulprakash completed his B.E. degree in Kumaraguru College of Technology, Coimbatore (Anna University, Coimbatore) in 2011. Now, he pursuing his M.E. degree in Kongu Engineering College, Perundurai. His area of interest includes Power Electronics \& Electric Drives 